\title{
Peningkatan Pengetahuan dan Keterampilan Kader Posyandu Balita melalui Pelatihan Pijat Bayi dalam rangka Meningkatkan Tumbang Kembang Bayi di Posyandu Flamboyan Desa Kandang Semangkon Kecamatan Paciran Kabupaten Lamongan
}

\author{
Arkha Rosyaria Badrus ${ }^{1 *}$, Kholifatul Ummah ${ }^{2}$ \\ ${ }^{1,2}$ Prodi D-III Kebidanan, Fakultas Ilmu Kesehatan, Universitas dr. Soetomo Surabaya \\ *rosse.arkha@gmail.com
}

Received 14 January 2019; Accepted 2 March 2019; Published 10 March 2019

\begin{abstract}
Indonesian Health Demographic Survey (SKDI) raises the average in Indonesia there are 401 babies who die before reaching the age of 1 year. Maternal and under-five mortality rates in Indonesia are still relatively high and have not reached national achievement targets. The maternal mortality rate in Indonesia is still relatively high at 359 per 100,000 live births. This figure is still far from achieving the national target of 102 per 100,000 live births. Based on the results of the Indonesian Demographic and Health Survey (IDHS) in 2012, the neonatal mortality rate in 2012 was 19 per 1000 live births. The most common causes in this period are caused by sepsis (systemic infection) congenital abnormalities, and acute respiratory tract infections. Seeing this condition requires a community service effort in the form of training for Posyandun cadres as a strategy to empower the community to improve maternal and child health at the Flamboyan Village Posyandu Semangkon Cage, Paciran Subdistrict, Lamongan Regency Activities were carried out several stages which included socialization of the importance of infant massage, training of toddlers posyandu cadres, training of toddlers posyandu cadres and family visits with mothers who have toddlers.
\end{abstract}

Keywords: Toddler cadre, infant massage, toddler growht and development

This is an open-acces article distributed under the terms of the Creative Commons Attribution-ShareAlike 4.0 International License.

\section{PENDAHULUAN}

\section{Analisis situasi}

Desa kandang Semangkon merupakan salah satu desa yang ada di Wilayah Kecamatan Paciran Kabupaten Lamongan. Desa Kandang Semangkon berada di sebelah utara laut jawa, batasbatas wilayah Kandang Semangkon adalah sebagai berikut:

Sebelah Utara : Laut Jawa

Sebelah Selatan : Desa Dadapan Kecamatan Solokuro

Sebelah Timur : Desa Paciran Kecamatan Paciran

Sebelah Barat : Kelurahan Blimbing Kecamatan Paciran

Desa Kandang Semangkon adalah wilayah padat penduduk yang sebagian besar masyarakatnya memiliki mata pencaharian pedagang dan nelayan, dimana pendidikan masyarakatnya masih rendah rata-rata masyarakat Kandang Semangkon memiliki pendidikan SMP dan SMA jumlah 
rata-rata penduduk 8.802 Jiwa, yang terdiri dari penduduk laki-laki 4.347 Jiwa dan 4.455 Jiwa merupakan penduduk perempuan sedangkan jumlah balita sebanyak 300 balita. Sehingga dengan pola pekerjaan dan pendidikan masyarakat yang masih rendah menyebabkan kurangnya pengetahuan dan keterapilan masyarakat tentang tumbuh kembang balita. Banyak masyarakat yang datang ke dukun pijat untuk memijatkan bayi dan balitanya dengan berbagai alasan, baik untuk menghilangkan capek pada bayi ataupun karena bayinya sakit.

Kesehatan bayi dan balita merupakan salah satu aspek yang prioritas untuk diperhatikan. Masa depan anak sangat ditentukan oleh kesehatan sejak dalam kandungan dan pada masa balitanya. Kesehatan ibu hamil perlu diperhatikan mengingat masih banyaknya kejadian komplikasi pada kehamilan dan persalinan yang akan berdampak pada kesehatan bayi yang dilahirkannya. Begitu pula kemampuan perawatan bayi baru lahir, pemenuhan ASI ekslusif dan gizi seimbang pada balita sangat penting diperhatikan untuk menjamin kesehatan dan perkembangannya.

\section{Rumusan Masalah}

1. Bagaimana memberikan pengetahuan kepada ibu kader dan ibu balita tentang manfaat pijat bayi?

2. Bagiamana caranya agar kader dan orang tua balita memiliki keterampilan teknik pemijatan bayi yang benar?

3. Bagaimana menumbuhkan pemahaman terhadap kader dan orang tua balita mengenai pentingnya pjat bati rutin secara mandiri.

\section{Tujuan Pengabdian Masyarakat}

1. Memberikan pemahaman kepada kader dan orang tua balita mengenai manfaat pijat bayi

2. Mengajarkan Tata Cara Dan Teknik Pijat Bayi Yang Benar

3. Menumbuhkan kemandirian pada kader dan orang tua balita untuk melakukan pemijatan terhadap bayinya secara rutin dengan teknik dan tata cara yang benar.

\section{Luaran yang diharapkan}

1. Ibu - Ibu Kader Posyandu Flamboyan Desa Kandang Semangkon diharapkan memiliki pengetahuan tentang pentingnya pijat bayi sehingga ilmu yang didaptakan dapat di transfer kepada ibu-ibu balita di wilayahnya.

2. Meningkatkan keterampilan kader posyandu Flamboyan Desa Kandang Semangkon tentang tentang pijat bayi yang benar sehingga dapat meningoptim alkan tumbuh kembang balita di wilayahnya.

3. Menumbuhkan kemandirian Ibu kader Posyandu Flamboyan Desa Kandang Semangkon sehingga dapat melakukan pemijatan kepada masayarakar, dan ibu balita secara mandiri.

\section{BAHAN DAN METODE}

Sesuai dengan tujuan yang telah dikemukakan maka metode kegiatan pengabdian masyarakat yang akan dilakukan adalah :

1. Menggunakan metode ceramah dan diskusi/ tanya jawab, digunakan pada waktu menyampaikan materi kegiatan yaitu materi tentang pentingnya pijat bayi untuk mengobtimalkan tumbuh kembang bayi.

\section{Journal of Community Engagement in Health}


2. Metode Demonstrasi serta latihan praktek, yang digunakan untuk mengajarkan pijat bayi kepada ibu - ibu kader posyandu Flamboyan Desa Kandang Semangkon sejumlah sebanyak 50 ibu kader posyandu, serta latihan dan menilai kemampuan masing- masing kader dalam melaukan pijat bayi dengan tepat dengan menggunakan panthom atau alat peraga bayi

3. Praktik Langsung Ke bayi , dimana ibu kader dan ibu balita melakukan pemijatan langsung kepada bayi, untuk menilai dan mempraktekkan langsung pijat bayi secara benar dan tepat.

\section{HASIL}

\begin{tabular}{|c|c|c|c|c|}
\hline $\begin{array}{c}\text { HARI } \\
\text { KE }\end{array}$ & TANGGAL & MATERI & JUMLAH PESERTA & HASIL \\
\hline 1 & 12 Maret 2018 & $\begin{array}{l}\text { Pretest kepada seluruh kader } \\
\text { psoyandu }\end{array}$ & 50 orang & $\begin{array}{c}\text { Kurangnya pengetahuan } \\
\text { pijat bayi pada peserta } \\
\text { sebesr } 50 \%\end{array}$ \\
\hline 2 & 20 Maret 2018 & a. Materi pijat bayi & 50 kader posyandu Falmboyan & - \\
\hline 3 & 20 Maret 2018 & $\begin{array}{l}\text { a. Demonstrasi pijat bayi } \\
\text { b. Praktik pijat bayi }\end{array}$ & 10 kader posyandu Falmboyan & - \\
\hline 4 & 03 April 2018 & $\begin{array}{l}\text { a. Demonstrasi pijat bayi } \\
\text { b. Praktik pijat bayi }\end{array}$ & 10 kader posyandu Falmboyan & - \\
\hline 5 & 04 April 2018 & $\begin{array}{l}\text { a. Demonstrasi pijat bayi } \\
\text { b. Praktik pijat bayi }\end{array}$ & 10 kader posyandu Falmboyan & - \\
\hline 6 & 10 April 2018 & $\begin{array}{l}\text { a. Demonstrasi pijat bayi } \\
\text { b. Praktik pijat bayi }\end{array}$ & 10 kader posyandu Falmboyan & - \\
\hline 7 & 11 April 2018 & $\begin{array}{l}\text { a. Demonstrasi pijat bayi } \\
\text { b. Praktik pijat bayi }\end{array}$ & 10 kader posyandu Falmboyan & - \\
\hline 8 & 25 April 2018 & $\begin{array}{l}\text { a. Praktik ulang pijat bayi } \\
\text { b. Post test }\end{array}$ & 10 kader posyandu Flamboyan & $\begin{array}{l}\text { Terdapat peningkatan } \\
\text { pengetahuan } \\
\text { keterampilan pada kader } \\
\text { posyandu dalam teknik pijt } \\
\text { bayi sebesar 20\% }\end{array}$ \\
\hline 9 & 26 April 2018 & $\begin{array}{l}\text { a. Praktik ulang pijat bayi } \\
\text { b. Post test }\end{array}$ & 10 kader posyandu Flamboyan & $\begin{array}{l}\text { Terdapat peningkatan } \\
\text { pengetahuan } \\
\text { keterampilan pada kader } \\
\text { posyandu dalam teknik pijt } \\
\text { bayi sebesar 20\% }\end{array}$ \\
\hline 10 & 02 Mei 2018 & $\begin{array}{l}\text { a. Praktik ulang pijat bayi } \\
\text { b. Post test }\end{array}$ & 10 kader posyandu Flamboyan & $\begin{array}{l}\text { Terdapat peningkatan } \\
\text { pengetahuan } \\
\text { keterampilan pada kader } \\
\text { posyandu dalam teknik pijt } \\
\text { bayi sebesar 20\% }\end{array}$ \\
\hline 11 & 03 Mei 2018 & $\begin{array}{l}\text { a. Praktik ulang pijat bayi } \\
\text { b. Post test }\end{array}$ & 10 kader posyandu Flamboyan & $\begin{array}{l}\text { Terdapat peningkatan } \\
\text { pengetahuan } \\
\text { keterampilan pada kader } \\
\text { posyandu dalam teknik pijt } \\
\text { bayi sebesar 20\% }\end{array}$ \\
\hline 12 & 15 Mei 2018 & $\begin{array}{l}\text { a. Praktik ulang pijat bayi } \\
\text { b. Post test }\end{array}$ & 10 kader posyandu Flamboyan & $\begin{array}{lr}\text { Terdapat } & \text { peningkatan } \\
\text { pengetahuan } & \text { dan } \\
\text { keterampilan pada kader } \\
\text { posyandu dalam teknik pijt } \\
\text { bayi sebesar } 15 \%\end{array}$ \\
\hline
\end{tabular}

Berdasarkan tabel pelaksanaan pelatihan pijat bayi didapatkan $50 \%$ pengetahuan kader posyandu Flamboyan kurang mengetahui tentang pijat bayi tetapi setelah dilakukan pelatihan kepada 50 kader dimana terbagi menjadi 10 kader yang pelaksanaannya kurang lebih 3 bulan dan setelah itu dilaksanakan post tes didapatkan peningkatan penegtahuan dan keterampilan pada kader posyandu sebesar $95 \%$.

\section{PEMBAHASAN}

Pelatihan pijat bayi merupakan salah satu bentuk kegiatan pengabdian masyarakat yang bertujuan untuk meningkatkan peran serta masyarakat dalam upaya meningkatkan derajat kesehatan ibu dan anak. Hal ini secara jangka panjang bertujuan untuk menurunkan angka kesakitan dan kematian ibu dan balita yang selama ini masih tergolong cukup tinggi di Indonesia. Kegiatan ini juga selaras dengan kegiatan pemerintah dalam hal meningkatkan pemberdayaan masyarakat dalam upaya mengurangi masalah kesehatan dan meningkatkan derajat kesehatan masyarakat khususnya pada

\section{Journal of Community Engagement in Health}


populasi ibu dan balita. Kegiatan ini juga bertujuan untuk memandirikan masyarakat dalam melakukan tata laksana masalah kesehatan ibu dan balita sebelum di bawa ke pelayanan kesehatan sehingga dapat dilakukan tata laksana lebih awal. Stanhope dan Lancaster (2012) menjelaskan bahwa resiko biologi adalah faktor genetik atau fisik yang ikut berperan dalam timbulnya resiko tertentu yang mengancam kesehatan. Faktor biologis yang melekat pada balita adalah faktor usia. Usia balita yang masih muda menyebabkan sistem kekebalan tubuh yang belum berkembang. Strategi intervensi dalam pengabdian masyarakat kali ini adalah pelatihan pijat bayi terhadap kader posyandu. Dampak positif yang ditimbulkan dari pijat bayi umumnya bayi yang mendapat pijatan secara teratur akan lebih rileks dan tenang. Melalui sentuhan pemijatan terhadap jaringan otot, peredaran darah dapat meningkat makin lancar, ataupun posisi otot dapat dipulihkan dan diperbaiki otomatis dapat meningkatkan fungsi-fungsi organ tubuh dengan sebaik-baiknya (Habibie, 1998 dalam Roesli, 2009). Sedangkan dampak negatif yang ditimbulkan bila pijat bayi dilakukan pemijatan dengan cara yang salah dan tidak sesuai dengan ketentuan medis. Efek samping dari kesalahan pemijatan diantaranya adalah pembengkakan, terdapatnya lebam, adanya rasa sakit pada bayi sehingga bayi menjadi rewel, pergeseran urat, cidera, bahkan bisa menyebabkan kematian pada bayi. Oleh karena itu, banyak orang tua enggan melakukan pijat bayi, mereka takut akan terjadi resiko pijat bayi pada buah hatinya. Resiko pijat bayi tersebut biasanya disebabkan oleh kelalaian praktisi pijat dalam memijat, salah pijat, dan kurangnya pengetahuan pemijat (Andria, 2011). Di Indonesia pemijatan tidak hanya dilakukan bila bayi sehat, tetapi juga saat bayi sakit atau rewel dan sudah menjadi rutinitas perawatan bayi setelah lahir (Roesli, 2009). Hasil kegiatan menunjukkan bahwa dari 50 kader posyandu flamboyan terdapat peningkatan pengetahuan sebanyak $95 \%$ dibandingkan sebelum dilakukan pelatihan.

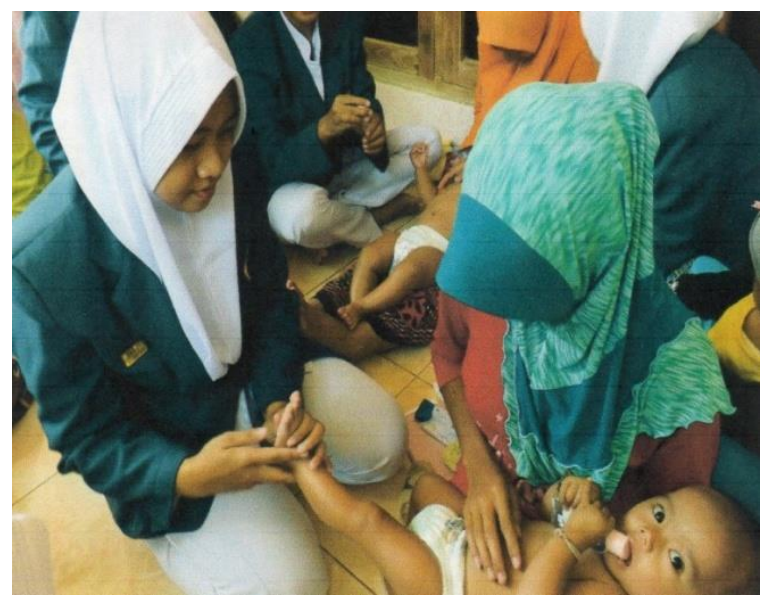

(Gambar 1. Pelaksanaan Pelatihan Pijat Bayi pada kader posyandu Flamboyan desa Kandang

Semangkon Kec.Paciran Kab.Lamongan dengan melibatkan mahasiswa)

\section{KESIMPULAN}

Pelatihan pijat bayi pada kader posyandu Flamboyan desa Kandang Semangkon Kecamatan Paciran kabupaten Lamongan merupakan suatu bentuk pemberdayaan masyarakat dalam upaya meningkatkan derajat kesehatan ibu, bayi dan balita. Pembentukan kelompok ini secara konkrit dapat memberikan dukungan dan motivasi ibu untuk terus menjaga kesehatan bayi dan balitanya. Kegiatan ini dapat menjadi wadah saling berbagi informasi dan dukungan antar anggota dan di luar anggota yaitu masyarakat desa Kandang Semangkon Kecamatan Paciran Kabupaten Lamongan pada umumnya. Harapannya kegiatanini dapat terus berlanjut untuk ke depannya secara mandiri.

\section{Journal of Community Engagement in Health}




\section{REFERENSI}

Abate, H., G., Makau, K., \& Sorensen, P. (2005). Risk factor for child undernutrition with a human right edge in rural villages of north wollo, ethiophia. East African Medical Journal. Vol 82,No 12, December 2005.

Allender, J., A., \& Spradley, B., W. (2014). Community health nursing: promoting and protecting the public health, $8^{\text {th }}$ edition. Philadelphia: Lippincott.

Kemenkes RI. (2013). Rencana Kerja Pembinaan Gizi Masyarakat Tahun 2013. Direktorat Bina Gizi dan KIA. Kementerian Kesehatan RI.

Roma. (2008). Seni Memijat Bayi yang Menyejukkan. Jakarta: Ladang Pustaka \& Intimedia.

Moersintowati, Sularyo, T., S., Soetjiningsih, dkk. (2002). Buku Ajar tumbuh Kembang Anak Edisi $k e-1$. IDAI.

Kementerian Kesehatan RI. (2010). Pedoman Kader Seri Kesehatan Anak.

Putri, \& Alissa, (2009). Pijat dan Senam Untuk Bayi dan Balita Panduan Praktis Memijat Bayi dan Balita. Yogyakarta: Brilliant Offset Roesli.

Utami. (2001). Pedoman Pijat Bayi (Edisi Revisi). PT. Trubus Agriwidya. Jakarta.

Subakti, Yazid, \& Anggraeni, D., R. (2008). Keajaiban pijat bayi dan balita. PT. Wahyu media. Jakarta.

Oktobrariani, R., R. (2010). Pengaruh Pendidikan kesehatan tentang pijat bayi terhadap praktik pijat bayi di polindes Harapan Bunda Sukoharjo. Universitas Muhammadiyah Surakarta. Diakses tanggal 05 Januari 2018.

\section{Journal of Community Engagement in Health}

